\title{
ダブルパルスレーザー誘起ブレークダウン分光法による水中 ナトリウムの高感度検出
}

内田 裕 $^{\circledR 1}$, 桑子 彰 $^{1}$, 小長井主税 ${ }^{1}$, 前田 克治 $^{2}$

\section{Super-sensitive detection of sodium in water using dual-pulse laser-induced breakdown spectroscopy}

\author{
Yutaka UCHIDA ${ }^{1}$, Akira Kuwako ${ }^{1}$, Chikara KonAGAI ${ }^{1}$ and Katsuji MaEdA ${ }^{2}$ \\ ${ }^{1}$ Power and Industrial System R\&D center TOSHIBA Co., 8 Shinsugita-cho, Isogo-ku, Yokohama-shi, Kanagawa \\ $235-8523$ \\ ${ }^{2}$ Isogo Nuclear Enginering Center TOSHIBA Co., 8 Shinsugita-cho, Isogo-ku, Yokohama-shi, Kanagawa 235- \\ 8523
}

(Received 23 January 2003, Accepted 12 April 2003)

\begin{abstract}
Laser-induced breakdown spectroscopy (LIBS) has been used for the detection of trace species in water. LIBS has the capability to be used for a real-time, in-situ analysis during power-plant operation. To improve the detection limit of the LIBS technique, a dual-pulse cross-beam scheme (DP-XB) was adopted. In this paper, we discuss the effects of the detector gate delay time, dual pulse interval, laser irradiating energies, and irradiating position for DP-XB LIBS. The signal-to-noise ratio $(S / N)$ was optimized when the laser irradiating energies were 240/200 $\mathrm{mJ}$, while the detector gate delay and pulse interval were $4 \sim 8 \mu \mathrm{s}$ and $8 \mu \mathrm{s}$, respectively. The linear correlation between the Na concentration and the fluorescence intensity was obtained from 1 to $100 \mathrm{ppb}$ and the limit of detection (LOD) for Na was $0.14 \mathrm{ppb}$.
\end{abstract}

Keywords : laser; spectroscopy; LIBS; Na.

\section{1 緒言}

高ピークパワーのレーザー光パルスを試料に照射して微 小プラズマを発生させ，その発光をもとに分析を行うレー ザー誘起ブレークダゥン分光法（laser induced breakdown spectroscopy, LIBS 法) は気体 ${ }^{1)}$, 固体 ${ }^{2)}$ ，エアロゾ ル ${ }^{3)}$ の分析手法として多くの研究が行われている. LIBS 法 ではレーザービームを試料に集光照射することにより試料 をプラズマ化するため，試料形態に依存することなく分析 が行うことができる。そのため通常の分析手法のように試 料をプラズマ化するための前処理が不必要であり, ICP 発 光分光法等に比べ迅速，簡便な分析法として期待されてい

\footnotetext{
株式会社東芝電力・産業システム技術開発センター: 235-8523 神奈川県横浜市磯子区新杉田町 8

2 株式会社東芝磯子エンジニアリングセンター: 235-8523 神奈 川県横浜市磯子区新杉田町 8
}

$ろ^{4)}$.

このような特性を生かして，近年の環境規制強化に伴う 火力発電プラントをはじめとする各種プラントにおけるオ ンライン，リアルタイム水質監視に用いることが検討され ている.また, 加圧水型原子炉 (PWR) プラントでは冷 却水の高 $\mathrm{pH}$ 運転が現在計画されているが，その場合では 復水器浄化系のバイパス運転が必須となるため, 冷却水中 への海水漏えいを高感度, リアルタイムで監視する必要が ある。

一方，現在までに報告されてきた LIBS 法を用いた水中 の $\mathrm{Na}$ 測定における検出下限は $0.4 \mathrm{ppb}$ であり ${ }^{5)}$, PWR プ ラントにおける管理值 $0.1 \mathrm{ppb}$ に対して検出感度が不足し ているため，オンライン，リアルタイム監視に適用できな い. 通常の発光分光分析と同様に，LIBS 法を用いた微量 元素分析の検出下限は検出対象元素からの発光スペクトル が背景に存在するプラズマの発光に埋もれてしまう濃度と 
なる.したがって，検出感度を向上させるためには，発光 スペクトル強度を増大させることと, 背景のプラズマ発光 強度を抑制することが重要になる，検出対象元素のスペク トル強度増大にはレーザー照射により生ずるプラズマ体積 の増大が有効であるが，単純に照射エネルギーを増加した 場合では同時に黒体ふく射としてのプラズマ発光も増加し てしまうことや，照射パルス前半でプラズマ密度が上昇し 電子密度が上昇する結果，パルス後半のエネルギーは試料 に注入できず，試料から生成されるプラズマ体積が増大さ れない, などの要因により検出感度向上とならない.また, 溶液試料に対して照射エネルギーの増大は試料液膜の摇ら ぎの増大などにより発光強度が変動するなどの問題を引き 起こす。このような課題に対して, 時間的に近接した $2 つ$ のレーザーパルスを試料に続けて照射することにより，最 初のレーザー照射により生成して照射領域に残存する粒子 を続くレーザー照射により再励起し効率的な原子発光を行 うダブルパルス照射法が，固体試料や液体試料を中心に試 みられている6

また，LIBS 法を単独で用いるのではなく，レーザー誘 起蛍光法 (laser induced fluorescence, LIF 法) を併用し, 検出感度向上を試みる研究も行われている7). この計測体 系では，レーザー照射から比較的大きな時間経過後に計測 することが可能となるため，プラズマからの黒体ふく射の 影響を受けにくくなり, 高感度検出が期待される. 一方, LIBS 法と LIF 法とを組み合わせた測定法では対象元素の 緩和過程中に比較的寿命の長い準位が存在し, その準位か ら適当な波長で効率的に励起可能な遷移が存在する必要が ある. 今回対象としている $\mathrm{Na}$ のようなアルカリ金属では, 共鳴準位に分布する励起粒子が多数である。一方, 共鳴準 位から上述したようなレーザー誘起蛍光法に適した遷移が そしいため, LIF 法を併用する利点が生じ難い．

今回ダブルパルス照射法に更にレーザーを試料に対し 2 方向から照射するクロスビーム法とを組み合わせた装置体 系での測定実験を行い, 各種パラメーター試験を実施し た。また，液体試料に対する LIBS 計測において分光セル 等に試料を封入しレーザーを集光，照射した場合，溶液に よりプラズマがクエンチされ，十分な発光強度が得られな い。また, 容器に入れた試料溶液上面の自由表面にレーザ 一照射した場合, プラズマ発生に伴うショック波等により 表面が大きく動摇し, パルスごとの発光強度に変動が生ず る.したがって, 今回の実験では試料をノズルょり大気中 に噴出させ，液膜を生成してレーザー照射した。

上記装置パラメーターの最適化により水中の $\mathrm{Na}$ に対し て $0.14 \mathrm{ppb}$ の検出下限を実証したので報告する.
2 実験

\section{$2 \cdot 1$ 実験装置}

実験に用いた装置体系の概略を Fig. 1 に示す. 励起光 源として 2 台の Nd: YAG レーザー \{ Quantel 製 Brilliant $\omega\left(\mathrm{P}_{1}: 80 \sim 240 \mathrm{~mJ}\right.$, パルス幅: $\left.5 \mathrm{~ns}, 10 \mathrm{~Hz}\right)$, Continuum 製 Surelite $\left(\mathrm{P}_{2}: 80 \sim 240 \mathrm{~mJ}\right.$, パルス幅: $\left.\left.5 \mathrm{~ns}, 10 \mathrm{~Hz}\right)\right\}$ の基本波（波長 $\lambda: 1.06 \mu \mathrm{m}$ ）を用いた。二つのレーザー ビームはハーフミラーにより 2 分割するのと同時に 2 台 のレーザーからのビームを互いに同軸になるよう合成し た。合成されたレーザービームはそれぞれ焦点距離 100 $\mathrm{mm}$ のレンズを用いて試料液膜上に集光した。この場合， 液膜上での最大レーザーパワー密度は $\mathrm{P}_{1}, \mathrm{P}_{2}$ 共〜 $1 \mathrm{GW} / \mathrm{mm}^{2}$ 程度と見積もられた。試料セルはテフロン製 で, 前面にはそれぞれ $45^{\circ}$ の角度で 5 か所の光学䆔が設け られている. 今回の実験では Fig. 1 に示すように, 直交 する左右方向からレーザー照射を行い, 中央の悹より蛍光 を測定した。

試料溶液はマイクロポンプにより循環し, 試料セル中央 に設置したスプレーノズルを用いて試料セル内に噴出させ 液膜を生成した。試料の流量が $200 \mathrm{ml} / \mathrm{min}$ 以下ではレー ザー照射により液膜が摇らぎ信号強度の変動が大きいが, それ以上の流量では信号強度の安定性は流量に依存しな い. 今回の実験では流量を $400 \mathrm{ml} / \mathrm{min}$ とし、レーザー照 射領域での液膜は幅 $6 \mathrm{~mm}$, 厚さ $0.2 \mathrm{~mm}$ 程度であり, 流 速は $5.5 \mathrm{~m} / \mathrm{s}$ と見積もられた。

発生した蛍光は径 $100 \mathrm{~mm}$, 焦点距離 $100 \mathrm{~mm}$ の集光レ ンズを用いて光ファイバー端に集光し, 分光器（JobinYbon HR320)，ICCD デイテクター（Andor 製 IntraSpec V）を用いて分光計測した.

レーザーの照射タイミング，パルス間隔はデジタルディ レージェネレーター（Stanford Research DG-535）により それぞれ個別に調整した。

発光を ICCD に取り込む測光時間幅 $\left(\tau_{\mathrm{m}}\right)$ は $10 \mu \mathrm{s}$ 一定 とした. ICCD からのスペクトル信号はパーソナルコンピ ユータ（PC）に取り込み， $\mathrm{NaD}$ 線（589.5，588.9 nm）の 信号強度として $589.3 \mathrm{~nm}$ 中心で波長幅 $1 \mathrm{~nm}$ の範囲を積 分した值からベースラインとして 591.5〜 592.5 nm にお ける発光強度の平均值を引いた值を信号 $(S)$ とし, 591.5〜 $592.5 \mathrm{~nm}$ に扔ける背景発光強度のばらつきの振幅をノイ ズ成分 $(N)$ として求め, その比である $S / N$ 比により評価 した。今回の実験ではすべての試験に対して 100 パルス （積算時間 $10 \mathrm{~s}$ ）の蛍光信号を $\mathrm{PC}$ 上に積算して, デー夕 解析を行った。

実験に用いた試料は原子吸光分析用 $\mathrm{Na}$ 標準液（関東化 学製）を超純水（関東化学製）で希採して使用した。検出 感度評価試験を除き， $10 \mathrm{ppb}$ 濃度の試料を用いて測定を 


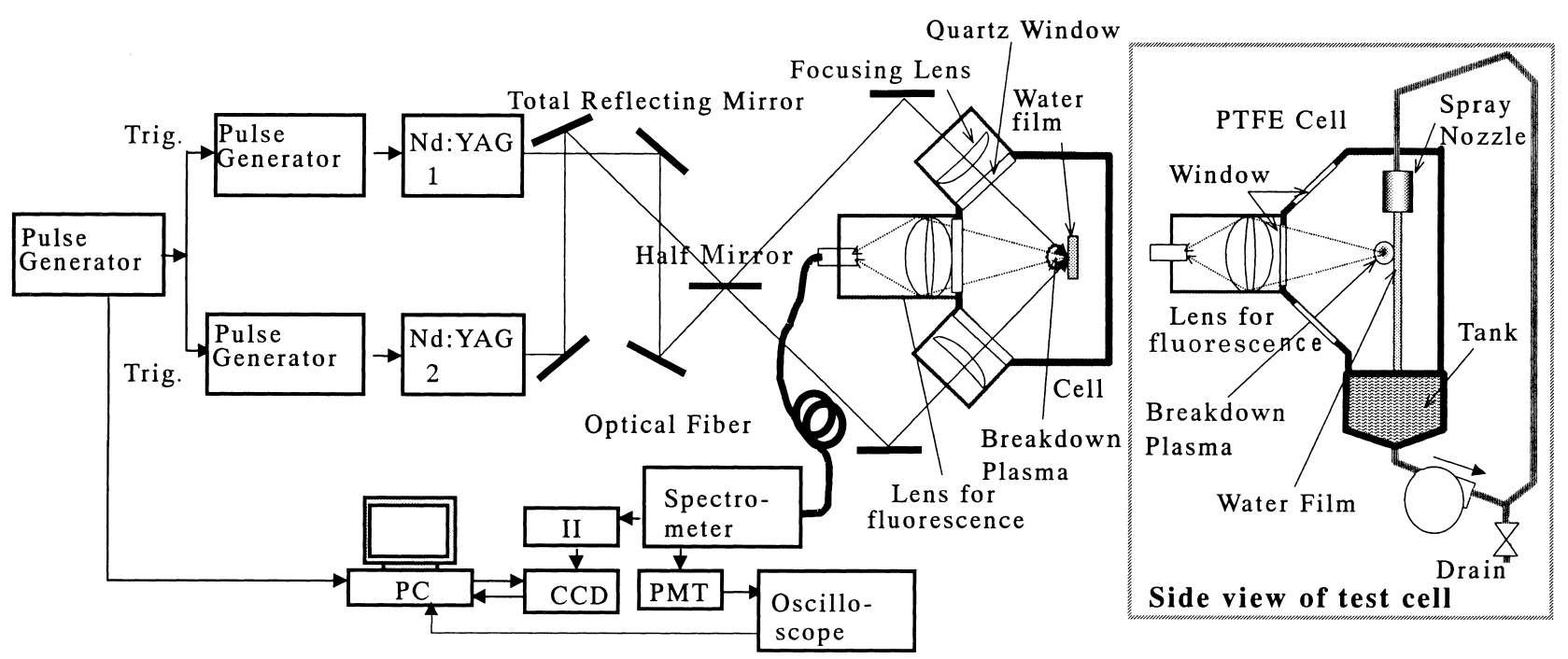

Fig. 1 Schematic diagram of experimental setup

Nd/YAG1: laser1, Nd/YAG2: laser2, II : Image-intensifier, CCD : CCD-array detector, PMT: Photomultiplier, PC: Personal computer

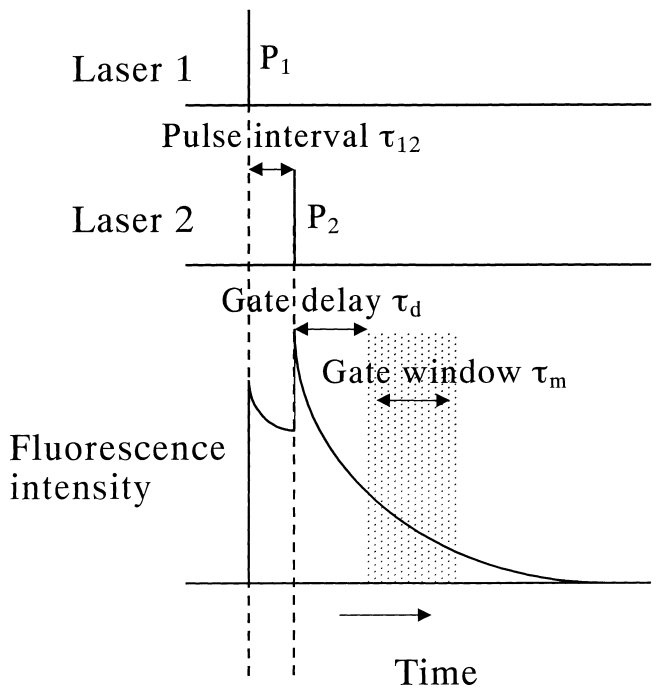

Fig. 2 Schematic diagram of measurement timing Where, $\mathrm{P}_{1}$ : Laser 1 pulse, $\mathrm{P}_{2}$ : Laser 2 pulse, $\tau_{12}$ : Pulse interval, $\tau_{\mathrm{d}}$ : Gate delay, and $\tau_{\mathrm{m}}$ : Detector gate window

行った.

\section{$2 \cdot 2$ 適正化パラメーター試験}

ダブルパルス照射に関するタイミング関係を模式的に Fig. 2 に示す. 本試験での最適化パラメーターとして, 後 続パルスのレーザー照射後から原子発光測定を行うまでの 時間：ゲート遅れ $\left(\tau_{\mathrm{d}}\right)$, 先行, 後続のレーザーパルス間 隔 $\left(\tau_{12}\right)$, 先行, 後続レーザーの照射エネルギー $\left(\mathrm{P}_{1}, \mathrm{P}_{2}\right)$ 及びレーザー照射位置を選び，実験を実施した。

\section{$2 \cdot 3$ ダブルパルス・クロスビーム構成の効果}

測定感度は照射レーザーエネルギーに依存すると考えら
れるため，照射レーザーエネルギーの総計值が同一となる 条件で各種照射形態での測定を行った。実験では照射レー ザーエネルギーの総計が $240 \mathrm{~mJ}$ となる条件として，照射 エネルギー $\mathrm{P}_{1}, \mathrm{P}_{2}$ を $120 \mathrm{~mJ}$ として左右両方向から照射し たダブルパルス，クロスビーム照射 $(\mathrm{DP} / \mathrm{XB}), \mathrm{P}_{1}, \mathrm{P}_{2}$ を $120 \mathrm{~mJ}$ としたダブルパルスで右あるいは左側からの一方 から照射したダブルパルスシングルビーム照射 $(\mathrm{DP} / \mathrm{SB})$, 照射エネルギー $240 \mathrm{~mJ}$ の単一パルス $\mathrm{P}_{1}$ を 2 分割し左右両 方向から照射したシングルパルス，クロスビーム照射 $(\mathrm{SP} / \mathrm{XB})$, 及び照射エネルギー $240 \mathrm{~mJ}$ の単一パルス $\mathrm{P}_{1}$ を 右あるいは左側からの一方向から照射したシングルパル ス，シングルビーム照射（SP/SB）の 4 通りを中心に実施 した。すべての測定におけるゲート遅れ $\tau_{\mathrm{d}}$ は $8 \mu \mathrm{s}$ 一定で あり，またダブルパルス照射でのパルス間隔 $\tau_{12}$ は $4 \mu \mathrm{s}$ と した。

\section{$2 \cdot 4$ 検出下限}

検出感度特性として $\mathrm{Na}$ 濃度 $1 \mathrm{ppb}$ 以下の試料を用いて 実験を行った場合，装置接液部への $\mathrm{Na}$ 吸着などの問題に より正確な測定を行うことが困難となる，そのため，今回 の実験では $\mathrm{Na}$ 濃度 $1 \mathrm{ppb}$ 以上の濃度が既知の $\mathrm{Na}$ 溶液を 試料として用い測定の線形性を評価した。また，検出下限 LOD（limit of detection）はLIBS 法における検出下限評 価に通常用いられている手法である ${ }^{5) 91}$, 純水における信 号強度の標準偏差 $\sigma$ 及び検量線の傾き $m$ より

$$
\mathrm{LOD}=3 \sigma / m
$$



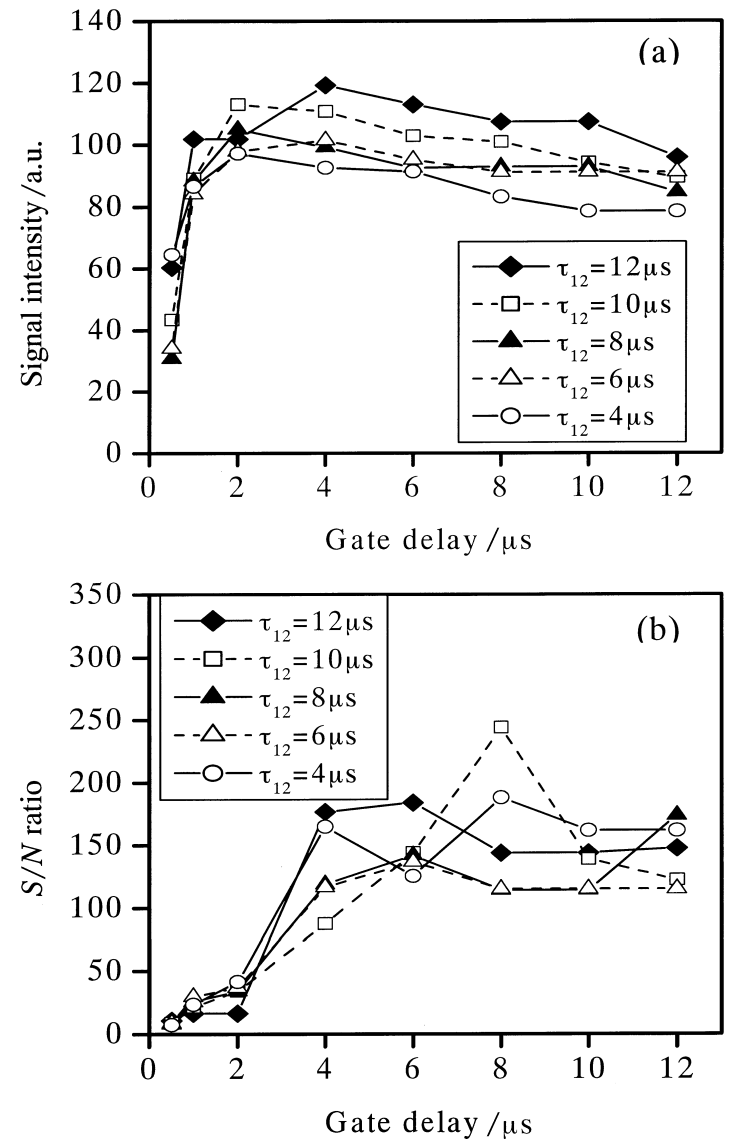

Fig. 3 Dependence of gate delay time of fluorescence intensity and $S / N$ ratio as a function of the pulse interval

The laser energy $\mathrm{P}_{1}$ and $\mathrm{P}_{2}$ are $220 \mathrm{~mJ}$ and $180 \mathrm{~mJ}$, respectively.

\section{3 結果と考察}

\section{$3 \cdot 1$ パラメーター試験結果}

ゲート遅れ依存特性では, 後続のレーザー照射から原子 発光計測までの時間 $\tau_{\mathrm{d}}$ を $0.5 \sim 12 \mu \mathrm{s}$ で変化させ，レーザ 一照射エネルギーは先行パルス $\mathrm{P}_{1}$ のエネルギー $220 \mathrm{~mJ}$, 後続パルス $\mathrm{P}_{2}$ のエネルギー $180 \mathrm{~mJ}$ で測定した. Fig. 3(a) に信号強度, Fig. 3(b) に $S / N$ 比のゲート遅れ時間 $\tau_{\mathrm{d}}$ 特 性を示す.ゲート遅れ $\tau_{\mathrm{d}}$ が $0.5 \mu \mathrm{s}$ ではプラズマの黒体ふ く射強度が大きく, Na からの元素発光はほとんど黒体ふ く射に埋もれた状態となる。ゲート遅れ増加に伴い黒体ふ く射は急速に減衰し, 相対的に $\mathrm{Na}$ 原子発光強度が増大し て $\tau_{\mathrm{d}} 2 \sim 4 \mu \mathrm{s}$ で最大となり, その後緩やかに減衰する. 信号の減衰傾向はパルス間隔 $\tau_{12}$ が短い場合により顕著に なる。一方， $S / N$ 比は遅れ時間 $\tau_{\mathrm{d}}$ 増加に伴いおよそ $6 \mu \mathrm{s}$ 近傍まで緩やかに増加し, その後緩やかに減少する. Na の蛍光強度は励起粒子の緩和により減少し時間経過に伴い 減少するが, 背景に存在するプラズマ発光強度はそれより も大きく減少するため, 結果として 6 〜 $10 \mu \mathrm{s}$ 後に $S / N$ 最

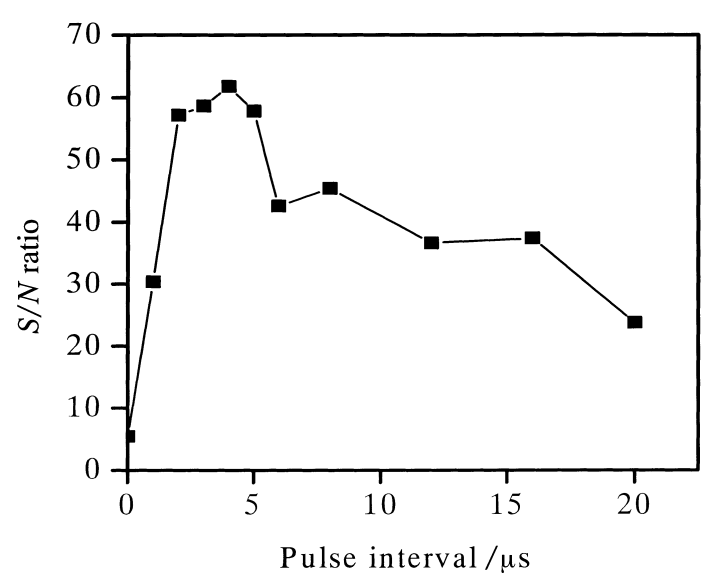

Fig. 4 Measured $S / N$ ratio versus pulse interval The laser energy $\mathrm{P}_{1}, \mathrm{P}_{2}$ are both $200 \mathrm{~mJ}$ and the gate delay $\tau_{\mathrm{d}}$ is $8 \mu \mathrm{s}$.

大点が出現する.

ダブルパルス照射におけるパルス間隔依存特性として, $\tau_{12}$ を 0 ～ $20 \mu \mathrm{s}$ の範囲で変化させ測定した.レーザー照射 エネルギーは $\mathrm{P}_{1}, \mathrm{P}_{2}$ 共に $200 \mathrm{~mJ}$ 一定とし, 蛍光測定まで の遅れ時間 $\tau_{\mathrm{d}}$ は $8 \mu \mathrm{s}$ 一定とした. Fig. 4 に $S / N$ 比のパル ス間隔依存特性を示す. 同時照射 $\tau_{12}=0$ では信号強度が 弱く $S / N$ 比は 5 程度であるが，パルス間隔 $\tau_{12}$ が $2 \sim 3 \mu \mathrm{s}$ において $S / N$ 比〜 50 程度になり，その後 $10 \mu \mathrm{s}$ 近傍まで $S / N$ 比はほぼ一定值を保つ。これは同時照射 $\tau_{12}=0$ では バックグラウンド発光が比較的強いことに対して, 元素発 光の強度が増強されていないため, 高い $S / N$ 比が得られ ない. 一方, パルス間隔 $\tau_{12}$ の増加に伴いバックグラウン ドのプラズマ発光は $\tau_{12}=0$ に対して減少するのと同時に, 元素発光強度は増加する.

照射エネルギー依存特性としてレーザー 1, レーザー 2 の照射エネルギーをそれぞれ $80 \mathrm{~mJ}$ から $240 \mathrm{~mJ}$ まで変化 させ，パルス間隔 $\tau_{12}$ は $4 \mu \mathrm{s}$ 一定，ゲート遅れ $\tau_{\mathrm{d}}$ は $8 \mu \mathrm{s}$ 一定で行った。Fig. 5 に照射エネルギーによる $S / N$ 比の 依存特性を示す。レーザー 1, レーザー 2 共にエネルギー を増加することにより $S / N$ 比の増大が認められる。これ は今回の実験範囲内では試料に対するレーザー照射エネル ギーが飽和しておらず，照射エネルギー増大に伴いプラズ マ体積及び励起粒子が増大するためと考えられる。また， 先行, 後続のレーザーエネルギー $\mathrm{P}_{1}, \mathrm{P}_{2}$ に関して, $\mathrm{P}_{1}$ の 変化のほうが $S / N$ 比にやや大きな影響を及ぼしている。 これは先行する照射レーザーエネルギーの増加は生成する プラズマ体積の増加を導き, 後続するレーザー照射エネル ギーの大小によらず再励起される粒子数の増加を促す。一 方，後続する照射レーザーエネルギーの増加は，照射空間 に存在する粒子の再励起に関与するため, 先行するレーザ 一照射により生成された励起粒子数密度が制約となるため 


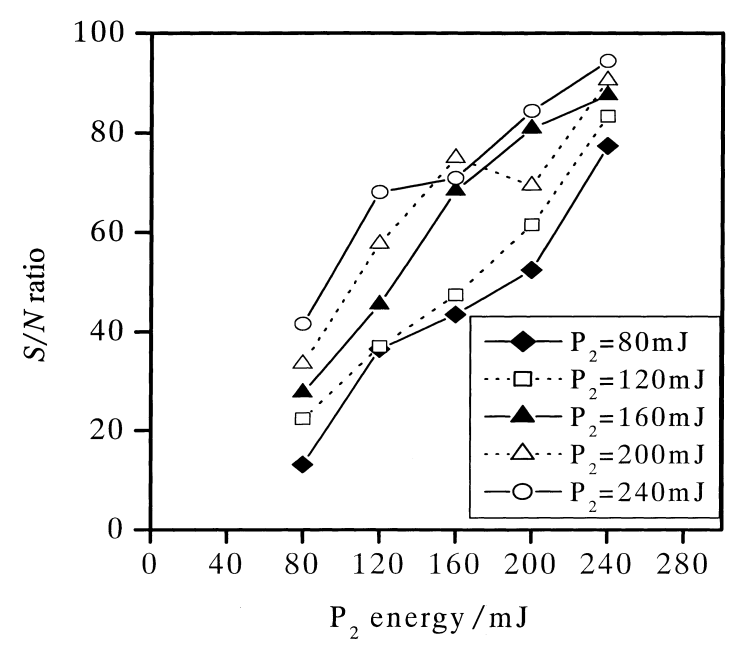

Fig. 5 Measured $S / N$ ratio versus first laser pulse energy $\mathrm{P}_{1}$ as a function of the second laser pulse energy $\mathrm{P}_{2}$

The gate delay $\tau_{\mathrm{d}}$ and pulse interval $\tau_{12}$ are $8 \mu$ s and 4 $\mu \mathrm{s}$, respectively.

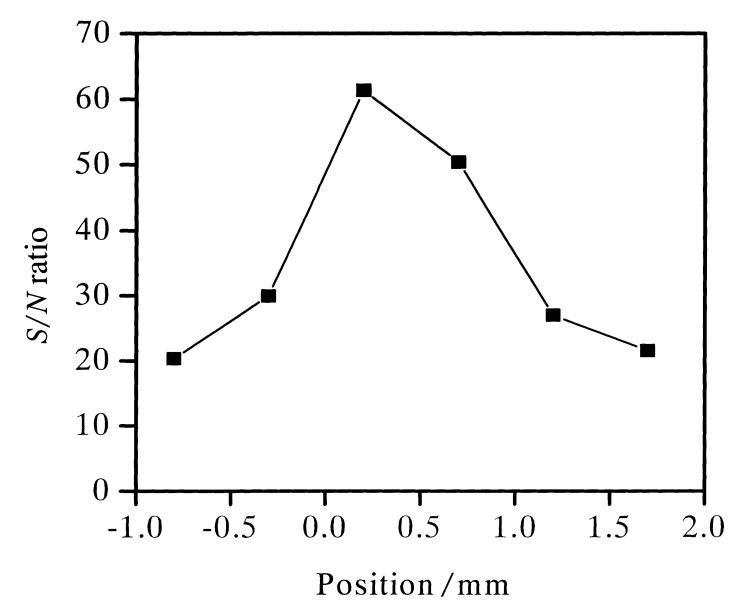

Fig. 6 Variation of measured $S / N$ ratio with irradiating position

The laser pulse energy $\mathrm{P}_{1}, \mathrm{P}_{2}$ are $200 \mathrm{~mJ}$, gate delay $\tau_{\mathrm{d}}$ and pulse interval $\tau_{12}$ are $8 \mu$ s and $4 \mu$ s, respectively.

である。

レーザー照射位置に関して, 左右両方向から試料液膜に 集光照射するレーザービームが液膜表面で交差する状態を 位置 0 として, 交差点と液膜との相対位置を変えて測定 した，位置表記として液膜よりビーム交差点が後方にある 状態を正として記述した。この測定では照射エネルギー $\mathrm{P}_{1}, \mathrm{P}_{2}$ を $200 \mathrm{~mJ}$ 一定, パルス間隔 $\tau_{12}$ を $4 \mu \mathrm{s}$ 一定, ゲー ト遅れ $\tau_{\mathrm{d}}$ は $8 \mu \mathrm{s}$ 一定とした. 測定結果を Fig. 6 に示す. $S / N$ 比が最も高くなるレーザー照射位置は試料液膜表面 より $0.1 \mathrm{~mm}$ 後方で 2 つビームが交差するような配置で ある．この配置ではビーム交差点が液膜より若干後方に位
Table 1 Measured $S / N$ ratio as a function of irradiation positions

\begin{tabular}{lcccccc}
\hline & \multicolumn{7}{c}{ Position } \\
\cline { 2 - 7 } & 0.2 & 0.1 & 0 & -0.1 & -0.2 & -0.3 \\
\hline$S / N$ ratio & 43.4 & 55.2 & 61.0 & 49.4 & 43.8 & 30.9 \\
Relative value & 0.71 & 0.90 & 1.0 & 0.81 & 0.72 & 0.51 \\
\hline
\end{tabular}

置し, 液膜表面でわずかに離れた 2 か所にレーザーが照 射されることになる，その結果， 2 つの近接したプラズマ が生成し, 空間的に一部が重なり合い密度の高い領域が生 成する. その結果, $\mathrm{Na}$ 励起効率が増大し, 高い $S / N$ 比が 得られると考えられる.

ビーム交差点が液膜よりも前方になる照射では液膜より も前方に高エネルギー密度領域が生じ, 液膜生成時に付帯 する飛まつにより液膜より前方の空間でブレークダウンが 生じてしまう。そのため, 液膜表面に到達するエネルギー が減少し, 効率的なプラズマ生成が行えない。 以上の要因 により, 交差点が液膜前方 $1 \mathrm{~mm}$ の位置で照射した場合, 最適照射に比べて $S / N$ 比は $1 / 3$ に低下した。一方，ビー ム交差点が液膜よりも後方になる照射では, 焦点位置が液 膜後方となるため液膜面上でのエネルギー密度が低くな り，プラズマ体積が減少する効果が主であり，試料への工 ネルギー注入が極端に低下することはない，そのため，交 差点が液膜後方 $1 \mathrm{~mm}$ の位置で照射した場合での $S / N$ 比 の低下は $1 / 2$ 程度である。最適照射位置近傍に扔ける測 定の $S / N$ 比変化を Table 1 に示す. 今回の実験体系では, レーザー照射位置が試料液膜表面より $0.1 \mathrm{~mm}$ 後方で $2 つ$ のビームが交差する点が最適であり，位置ずれに対して $S / N$ 比変動は $-0.1 \mathrm{~mm}$ では $10 \%,+0.1 \mathrm{~mm}$ では $20 \%$ に 収まっている。

\section{$3 \cdot 2$ ダブルパルス・クロスビーム構成の効果}

レーザー照射により生ずる $590 \mathrm{~nm}$ 近傍における発光の 緩和波形を Fig. 7 に示す。この図ではシングルパルス照 射の照射タイミングをダブルパルス照射における後続パル スを照射したタイミングに合わせて表示してある。シング ルパルス照射では，レーザー照射 $25 \mu \mathrm{s}$ 後に発光がほぼ消 滅しているが, ダブルパルス照射では $100 \mu \mathrm{s}$ 近傍まで発 光が持続している.レーザー照射後 $1 \mu \mathrm{s}$ 以後でのこの発 光は $\mathrm{Na}{ }^{2} \mathrm{P}_{1 / 2,3 / 2}{ }^{2} \mathrm{~S}_{1 / 2}$ 遷移による原子発光 ( $\mathrm{D}$ 線) である. したがって，Fig. 7 に示すように，ダブルパルス照射では $\mathrm{D}$ 線発光の上準位 $3^{2} \mathrm{P}_{1 / 2,3 / 2}$ の寿命よりはるかに長い時間 原子発光が持続している.

各種照射形態をパラメーターとして得られた $S / N$ 比を Table 2 に示す.トータル照射エネルギー $240 \mathrm{~mJ}$ の条件 で比較した場合，シングルパルス/シングルビーム照射 


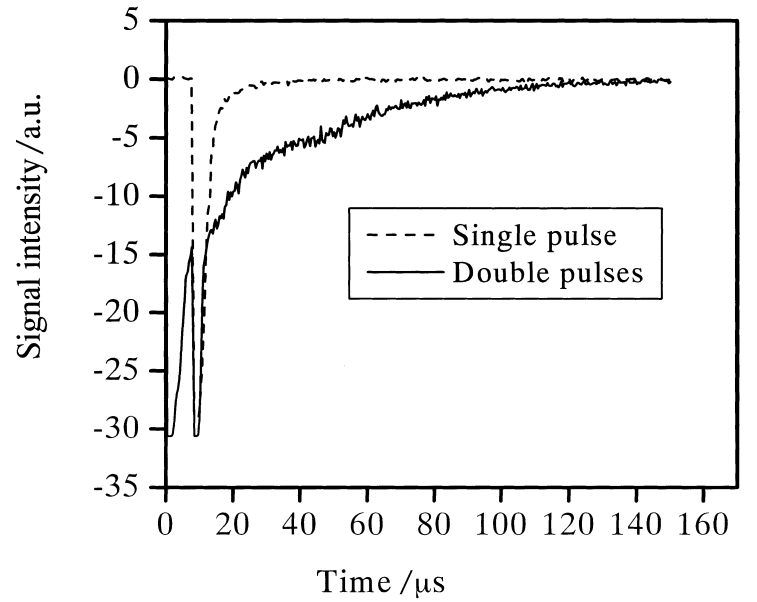

Fig. 7 Temporal waveform of LIBS fluorescence Horizontal scale is $25 \mu \mathrm{s} /$ div. Laser pulse energy $\mathrm{P}_{1}$, $\mathrm{P}_{2}$ are $240 \mathrm{~mJ}$ and $180 \mathrm{~mJ}$, respectively, gate delay $\tau_{\mathrm{d}}$ and pulse interval $\tau_{12}$ are $8 \mu \mathrm{s}$ and $4 \mu \mathrm{s}$, respectively.

Table 2 Measured $S / N$ ratio as a function of irradiation scheme

\begin{tabular}{cccccc}
\hline $\begin{array}{c}\text { Pulse } \\
\text { interval } \\
\tau_{12}\end{array}$ & $\begin{array}{c}\text { Pulse energy } \\
\left(\mathrm{P}_{1} / \mathrm{P}_{2}\right) \\
/ \mathrm{mJ}\end{array}$ & $\begin{array}{c}\mathrm{DP} / \mathrm{XB} \\
(S / N)\end{array}$ & $\begin{array}{c}\mathrm{DP} / \mathrm{SB} \\
(S / N)\end{array}$ & $\begin{array}{c}\mathrm{SP} / \mathrm{XB} \\
(S / N)\end{array}$ & $\begin{array}{c}\mathrm{SP} / \mathrm{SB} \\
(S / N)\end{array}$ \\
\hline $4 \mu \mathrm{s}$ & $120 / 120$ & 27.35 & 22.98 & 14.78 & 10.49 \\
& $120 / 60$ & 21.6 & 22.20 & - & - \\
\multirow{2}{*}{$8 \mu \mathrm{s}$} & $120 / 120$ & 15.97 & 26.46 & 14.78 & 10.49 \\
& $120 / 60$ & 18.01 & 18.06 & - & - \\
\hline
\end{tabular}

（SP/SB）に比べてクロスビーム化（SP/XB）により 1.4 倍程度 $S / N$ 比が改善される. また, シングルビーム/シン グルパルス照射と比ベダブルパルス化（DP/SB）により 同様に 2 倍程度 $S / N$ 比が改善される. 更にダブルパルス/ クロスビーム照射 (DP/XB) によりシングルパルス/シン グルビーム照射に比べて 2.6 倍程度 $S / N$ 比が改善される が， $S / N$ 比向上はそれぞれの改善効果の積 2.8 より若干小 さい值となった。この結果はダブルパルス照射, クロスビ 一ム照射の効果に若干の相互作用が存在する可能性を示唆 している. また, Fig. 4 に示すように, 今回実験した最大 エネルギーである $\mathrm{P}_{1} / \mathrm{P}_{2}: 240 / 240 \mathrm{~mJ}$ (トータル $480 \mathrm{~mJ}$ ) 条件で測定を実施したパルス間隔依存特性において, シン グルパルス照射である $\tau_{12}: 0 \mu \mathrm{s}$ では $S / N$ 比 5.4 が得られ た。一方, 最良の $S / N$ 比が得られる条件は $\tau_{12}=4 \mu \mathrm{s}$ であ り, その場合得られる $S / N$ 比は 61 となり, ダブルパルス 化による $S / N$ 比改善効果は 11 倍程度となる。この結果よ りダブルパルス, クロスビーム照射による効果は照射エネ ルギーが大きい条件においてより顕著に現れると考えられ る.

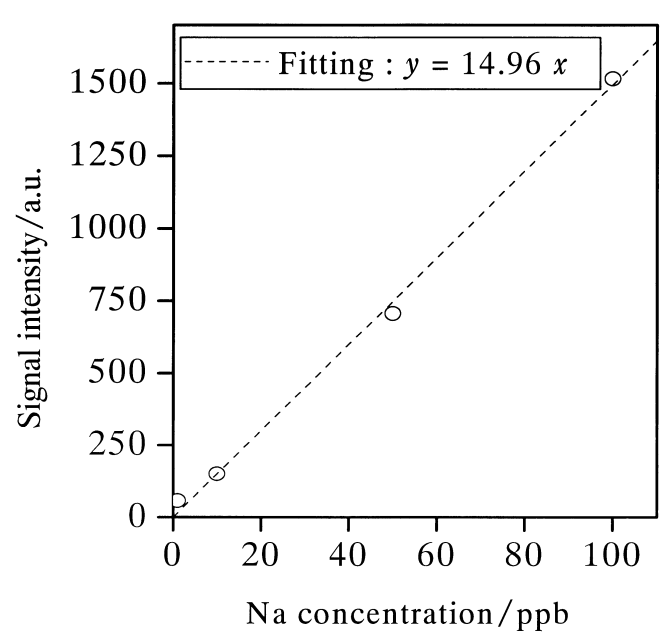

Fig. 8 Calibration curve of $\mathrm{Na}$ in water

The best linear fit is also shown. The corresponding slope $m$ is $14.96 \mathrm{ppb}^{-1}$.

ダブルパルス照射では先行レーザー照射により生成され レーザー照射領域に残存する元素が, 後続パルスにより再 励起される。この場合 $\mathrm{Na}$ 等を含む粒子はレーザー焦点位 置を中心に空間的に広がっており，後続パルスにより生成 されるプラズマ体積は相対的に拡大する. 更に残存粒子を 励起するためには試料水溶液を蒸散, プラズマ化するより も小さなエネルギーで十分であり, 励起効率も高くなる.

また，クロスビーム化によっても発生するプラズマ体積 が空間的に増大すると考えられるが，単にプラズマ体積の 増大だけでは信号強度と同時にバックグラウンドも同等に 増加するため, $S / N$ 比の改善にはならない. 大気中のレ ーザーブレークダウンにおけるプラズマの拡散速度は $1000 \mathrm{~m} / \mathrm{s}$ 程度と報告されており ${ }^{8)}$, クロスビーム照射体系 では生成したプラズマ（長さ〜0.5 mm）がプラズマ生成 直後から $0.5 \mathrm{~ms}$ の時間にわたり直交して衝突することに なる。その結果, プラズマの衝突過程により励起効率が向 上すると考えられる。

このような効果により，ダブルパルス，クロスビーム照 射では蛍光強度の向上が達成され， $S / N$ 比改善が達成さ れると考えられる。

\section{$3 \cdot 3$ 検出下限}

試料濃度に対する信号強度及び測定の $S / N$ 比を Fig. 8 に示す．この測定ではレーザー照射エネルギー $\mathrm{P}_{1}, \mathrm{P}_{2}$ は それぞれ $240,200 \mathrm{~mJ}$ であり，ゲート遅れ $\tau_{\mathrm{d}}$ を $8 \mu \mathrm{s}$, パ ルス間隔 $\tau_{12}$ は $4 \mu \mathrm{s}$ で行った。また，Fig. 9 に Na濃度 1 ppb 試料を用いて測定されたスペクトルを示す.

$\mathrm{Na}$ 濃度 1〜 $100 \mathrm{ppb}$ の範囲において信号強度は良好な 直線性が認められている. Fig. 8 に示した検量線の傾きは 14.96 であり，また背景信号の標準偏差は 0.723 である. 


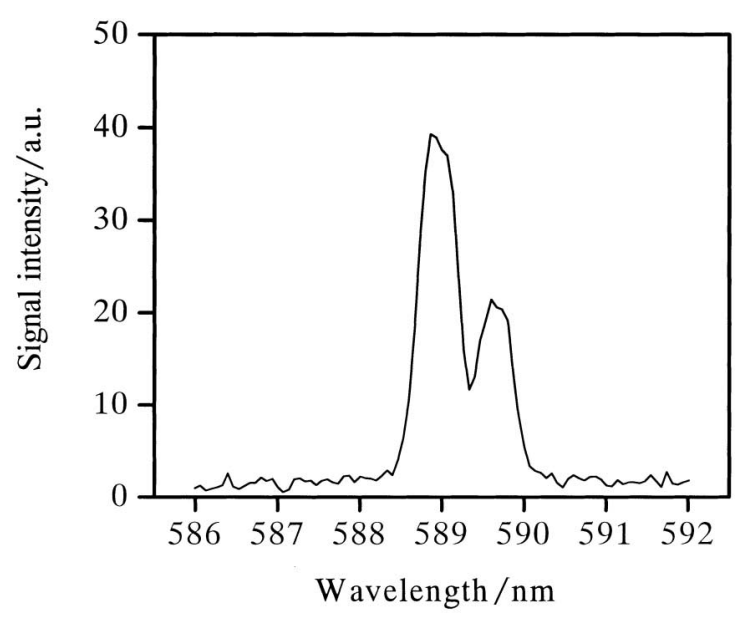

Fig. 9 Time-integrated LIBS spectra of sodium

Laser energies $\mathrm{P}_{1}, \mathrm{P}_{2}$ are $240 \mathrm{~mJ}$ and $200 \mathrm{~mJ}$, respectively, gate delay $\tau_{\mathrm{d}}$ and pulse interval $\tau_{12}$ are $8 \mu$ s and 4 $\mu \mathrm{s}$, respectively. Solution concentration: $1 \mathrm{ppb}$, and signal accumlation is 100 shots $(10 \mathrm{~s})$.

式（1）を用いて計算した結果, 検出限界は $0.14 \mathrm{ppb}(140$ ppt）と見積もられた。 $\left(\begin{array}{c}\text { 本研究の一部は LIBS2002 Sept.25〜28 } \\ \text { (2002) \{Optical Society of America（OSA） } \\ \text { 主催 Orlando Florida\} において一部発表 }\end{array}\right)$

\section{文献}

1) D. A. Cremers, L. J. Radziemski : Anal. Chem., 55, 1252 (1983).

2) H. Zhang, F. Y. Yueh, J. P. Singh: Appl. Opt., 38, 1459 (1999).

3) M. H. Nunez, N. Omenetto: Appl. Spectrosc., 55, 809 (2001).

4) O. Samek, D. C. S. Beddows, J. Kaiser, S. V. Kukhlevsky, M. Liska, H. H. Telle, J. Young: Opt. Eng., 39, 2248 (2000).

5) K. M. Lo, N. H. Chenug: Appl. Spectrosc., 56, 682 (2002).

6) D. N. Stratis, K. L. Eland, S. M. Angel: Appl. Spectrosc., 55, 1297 (2001).

7) M. Nakane, A. Kuwako, K. Nishizawa, H. Kimura, C. Konagai, T. Okamura: "Proc. SPIE-Int. Soc. Opt. Eng. (USA)", Vol.3935, p. 122 (2000).

8) S. Nakamura, Y. Ito, K. Sone, H. Hiraga, K. Kananeko: Anal. Chem., 68, 2981 (1996).

9) H. Zhang, F-Y. Yueh, P. Singh: Appl. Optics., 38, 1459 (1999).

\section{要旨}

オンライン，リアルタイム計測に適用可能なレーザー誘起ブレークダウン分光法（LIBS）を用いた元素 分析法に関し，2つのパルスを微小パルス間隔で照射するダブルパルス照射を行い，更にレーザーを試料の 左右方向から同時に照射するクロスビーム照射を組み合わせ, 高感度化を図った。レーザー照射エネルギー, ゲート遅れ，パルス間隔などをパラメーターとした試験を実施し，それらの最適化を行った。その結果，レ ーザー照射エネルギー $\mathrm{P}_{1} / \mathrm{P}_{2}=240 / 200 \mathrm{~mJ}$, ゲート遅れ $\tau_{\mathrm{d}}=8 \mu \mathrm{s}$, パルス間隔 $\tau_{12}=4 \mu \mathrm{s}$ の条件において, 水中 $\mathrm{Na}$ 濃度 1 〜 $100 \mathrm{ppb}$ の範囲で良好な直線性を確認した。 また，検量線の傾き及び背景信号のばらつき から求めた検出下限は $0.14 \mathrm{ppb}$ と見積もられた。 